\section{Polar forests of the past}

\section{from Simon Conway Morris}

FossiL organisms or associations, in particular reefs and luxuriant vegetation, are regarded as amongst the most reliable indicators of past climates and environments. What, then, are we to make of the existence of polar forests in the Cretaceous and Lower Tertiary? The suggestion that they can be accounted for by a lower obliquity of the Earth then than now is impossible to maintain in the face of a paper published by E.J. Barron in Geology ${ }^{1}$.

Cretaceous and Lower Tertiary fossil flora, include forests, where some trees have a trunk diameter greater than $50 \mathrm{~cm}$ at palaeolatitudes up to $85^{\circ}$, well beyond the present-day tree-line. Appeals to tectonic rafting from sunnier climes to a frigid docking may explain a few examples, such as those in Alaska ${ }^{2}$, but the majority of forests appear to be genuinely in situ. Of these, probably the most remarkable is the fossil forest in Alexander Island, Antarctica for which Jefferson ${ }^{3}$ was able to provide a detailed reconstruction, including information on the original spacing of trees (about 1 per $17.5 \mathrm{~m}^{2}$ ) and flood-induced reaction wood. That these high-latitude environments must have been radically different from those existing today is selfevident. To explain the location of the polar forests, repeated appeals have been made to a marked decrease in the Earth's obliquity with sharply diminished seasonality and more evenly spaced photoperiods ${ }^{4-8}$. Although palaeontology has played a not insignificant, if belated, role in upsetting other geophysical applecarts, such as the fixity of continents, it has seemed increasingly improbable that shifts in obliquity during geological time ${ }^{9}$ are a realistic proposition. First, the celestial mechanisms to effect such a displacement are far from evident ${ }^{10}$, and now Barron's more earth-bound evidence looks like setting a firm seal on the debate.

Barron has modelled the likely temperature distributions on a Cretaceous world with the obliquity reduced from the present $23^{\circ}$ to either $15^{\circ}$ or $5^{\circ}$. His analysis relies on a general circulation atmospheric model coupled to a simple ocean model. Although making a number of simplifications, this seems to provide reliable firstorder explanations. The paradoxical upshot is that a reduced obliquity exacerbates the problems of growing forests near the poles. This arises from a dramatic reduction in mean annual polar insolation, which more than off-sets the decreased seasonality and increased winter values of insolation, with a poleward transfer of heat that is unable to compensate for this loss. The calculated temperature distribution is not very different from that observed today (the northern Hemisphere would have been even colder than now), so the existence of highlatitude forests is highly improbable.

In fact, the evidence for a warm and equable Cretaceous planet with no ice-caps or winter freezing is overwhelming ${ }^{1,11}$, and it is the warmth at high latitudes that seems to resolve the enigma of their flora $2,12,13$. Evidence suggests that temperature is more of a limiting factor than light for plants ${ }^{13}$ (for a dissenting view, see ref. 7), hence the flourishing tropical and subtropical flora of Swedish botanical gardens, where the glass-houses are heated and watered but receive only natural daylight ${ }^{2}$. It is perhaps natural to think of Cretaceous forests engulfed in protracted polar nights but, contrary to the opinions of many authors (for example ref. 4), this is not incompatible with their existence. Today, annual insolation at locations well south of the Antarctic Circle can exceed that of East Anglia $^{13}$ (which comes as no surprise to this writer). Moreover, the plants of highlatitude Cretaceous forests may have specific adaptations to intercept the maximum sunlight, including a conical shape and appropriate spacing of the trees ${ }^{13}$, large leaves ${ }^{14}$, or various physiological adaptations, especially amongst the evergreens, that enabled them to overwinter ${ }^{2}$. Calculations suggest that not only would there have been a sufficient growing season with $360^{\circ}$ illumination for two months of the summer, but the annual biomass laid down as woody tissue is well within the limits set by the available energy flux ${ }^{13}$.

The higher mean annual temperatures of the Cretaceous polar regions may be only a partial explanation for their biota. If levels of atmospheric $\mathrm{CO}_{2}$ were higher than today ${ }^{15}$, this too may have had a beneficial influence on plant growth as well as helping to elevate planetary temperatures via the 'greenhouse effect' in the first place. Few authors ${ }^{13}$ appear to have given more than passing thought to this possibility, but the implications are intriguing. Concern about the release of anthropogenic $\mathrm{CO}_{2}$ is leading to new assessments of the likely effects on plant life. Data are seriously wanting, but the bulk of evidence points to greater productivity and, perhaps, increased tolerance to stress factors such as extreme temperatures and drought ${ }^{16}$. Could it be that the Cretaceous and Lower Tertiary polar forests owe their existence in part to higher $\mathrm{CO}_{2}$ levels ${ }^{1}$ ? Experiments on living relatives of the fossil plants may well be illuminating in this respect.

Interactions between palaeoclimatologists and palaeontologists are of more than academic interest. Convincing climatic modelling, whether it be for the Recent or the Cretaceous, where palaeontological evidence provides independent tests, strengthens belief that it is possible to predict accurately the effects of major increases in $\mathrm{CO}_{2}$ or the reality of a nuclear winter (see Nature News \& Views 312, 593; 1984). When the planet next reverts to a Cretaceous climate, it seems more than likely that the forests will return to the Antarctic peninsula, while alligators bask in the long polar summers and hibernate through the torpid winters.

1. Barron, E.J. Geology 12, 595 (1984).

2. Axelrod, D.I. Palaeogeog. Palaeoclimatol. Palaeoecol. 45, 105 (1984).

3. Jefferson, T.H. Palaeontology 25, 681 (1982).

4. Douglas, J.G. \& Williams, G.E. Palaeogeog. Palaeoclimatol. Palaeoecol. 39, 171 (1982).

S. Wolfe, J.A. Prof. Pap. U.S. geol. Surv. 997, 1 (1977).

6. Wolfe, J.A. Am. Scient. 66, 691 (1978)

7. Wolfe, J.A. Palaeogeog. Pr areoclimatol. Palaeoecol. 30, 313 (1980).

8. Truswell, E.M. in Paleoreconstruction of the Continents (eds McElhinney, M.W. \& Valencio, D.A.) Geodynamics Series 2, 13 (1981)

9. Williams, G.E. J. geol. Soc. Lond. 130, 599 (1974).

10. Ward, W.R. Jcarus 50, 444 (1982).

11. Barron, E.J. Earth Sci. Rev. 19, 305 (1983).

12. Schweitzer, H.J. Palaeogeog. Palaeoclimatol. Poloedecol. 30, 297 (1980)

13. Creber, G.T. \& Chaloner, W.G. in Fossils and Climate (ed. Brenchley, P.J.), 49 (1984).

14. Hickey, L. I3th Int. Bot. Congr. Abstr. 197 (1981).

15. Berner, R.A., Lasaga, A.C. \& Garrels, R.M. Am. J. Sci. 283, 641 (1983).

16. Lemon, E.R. (ed.) A.A.A.S. Select. Symp. 84 (1983).

Simon Conway Morris is in the Department of Earth Sciences, University of Cambridge, Cambridge CB2 $3 E Q$, UK.

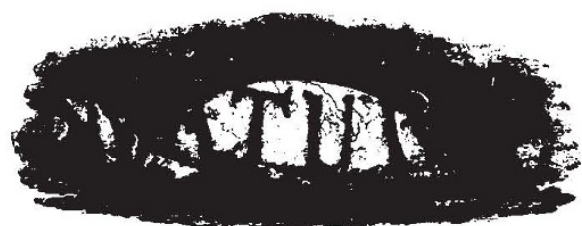

100 years ago

ROYAL SOCIETY February 12,-" On the Underground Temperatures, with Observations on the Conductivity of Rocks, on the Thermal Effects of Saturation an Imbibition, and on a Special Source of Heat in Mountain Ranges." By Joseph Prestwich, M.A., F.R.S., Professor of Geology in the University of Oxford.

The author remarks on the difference of opinion between physicists and geologists respecting the probable thickness of the outer crust of the earth. The question of underground temperature, which is a subject equally affecting the argument on both sides, had engaged the author's attention in connection with an inquiry respecting volcanic action, and he was induced to tabulate the results to see how far the usually received rates of increase were affected by various interfering causes-not that most of them had not received due attention, but it was a question of whether sufficient allowance had been made for them.

Although Gensanne's first experiments were made in 1740, and others were subsequently made by Daubuission, Saussure, and Cordier, in coal and other mines, it was not until the construction of deep artesian wells commenced in the second quarter of this century, and Walferdin introduced his overflow thermometer, and precautions were taken against pressure, that the more reliable observations were made. But notwithstanding the precautions taken, and the accuracy of the experiments, they present very wide differences in the thermometric gradient. From Nature 31 399, 26 February 1885. 